\title{
Guidelines for Organic Handling Requirements for Citrus Packinghouses and Processors ${ }^{1}$
}

James J. Ferguson and Mark A. Ritenour ${ }^{2}$

In 1990, Congress passed the Organic Foods Production Act, part of the 1990 Farm Bill, requiring the USDA to develop national standards for organically produced agricultural products. This was done to assure consumers that agricultural products marketed as organic meet consistent, uniform standards. After ten years of debate and discussion, the final rule of the National Organic Program (NOP) was published in the Federal Register in December, 2000 and fully implemented in October 21, 2002.

This final rule codifies the National Organic Program and refers to specific regulations whereas the National Organic Program refers to the overall program established by the federal Organic Foods Production Act of 1990. The full text of the final rule is available at http://www.ams.usda.gov/nop/NOP/standards/ FullText.pdf and contains information about all aspects of organic certification, production, packaging, processing, labeling, and retailing.

The final rule of the NOP contains both general guidelines about packaging and processing of organically grown crops and a National List of primary or generic lists of allowed, regulated, and prohibited inputs of synthetic and nonsynthetic materials as well as conditions regulating their use. However, the National List does not contain brand name products or manufacturers. That information is provided by the Organic Materials Review Institute (OMRI at http://www.omri.org), a private company that, for a fee, reviews and lists agricultural inputs for their suitability in certified organic production. The National List of organic inputs is also not a permanent list. A sunset provision provides for materials to remain on the National List for five years but this time could be reduced. The OMRI list may also contain similar provisions

Using the final rule of the National Organic Program as a basis, our purpose here is to provide general guidelines for organic handling requirements for citrus packing houses and processors by either directly or indirectly restating provisions of the final rule. Relevant sections of the final rule in the Federal Register, December 21, 2000, are cited for each topic covered. Since regulations affecting organic production are complex, detailed, and can vary according to national and international organic standards, growers should consult with their respective USDA-approved organic certifying agencies to resolve further questions.

1. This document is HS983, one of a series of the Horticultural Sciences Department, Florida Cooperative Extension Service, Institute of Food and Agricultural Sciences, University of Florida. Publication date: July 2004. Please visit the EDIS Web site at http://edis.ifas.ufl.edu.

2. James J. Ferguson, professor, Horticultural Sciences Department, and Mark A. Ritenour, assistant professor, Indian River REC-Ft. Pierce, Cooperative Extension Service, Institute of Food and Agricultural Sciences, University of Florida, Gainesville, 32611.

The Institute of Food and Agricultural Sciences (IFAS) is an Equal Opportunity Institution authorized to provide research, educational information and other services only to individuals and institutions that function with non-discrimination with respect to race, creed, color, religion, age, disability, sex, sexual orientation, marital status, national origin, political opinions or affiliations. U.S. Department of Agriculture, Cooperative Extension Service, University of Florida, IFAS, Florida A. \& M. University Cooperative Extension Program, and Boards of County Commissioners Cooperating. Larry Arrington, Dean 


\section{Packinghouses}

The handler of an organic handling operation must implement measures necessary to prevent the commingling of organic and nonorganic products and protect organic products from contact with prohibited substances.

The following are prohibited for use in the handling of any organically produced agricultural product:

- packaging materials and storage containers, or bins that contain a synthetic fungicide, preservative, or fumigant

- the use or reuse of any bag or container that has been in contact with any substance in such a manner as to compromise the organic integrity of any organically produced product or ingredient placed in those containers, unless such reusable bag or container has been thoroughly cleaned and poses no risk of contact of the organically produced product or ingredient with the substance used. (Section 205.272)

\section{Processing}

The following criteria will be utilized in the evaluation of substances or ingredients for the organic production and handling sections of the National List (Section 205.600).

- The substance can be used if it cannot be produced from a natural source and no organic substitutes are available.

- Manufacture, use, and disposal of the substance does not have an adverse effect on the environment and are done in a manner compatible with organic handling.

- The nutritional quality of the food is maintained when the substance is used and breakdown of the substance itself or its breakdown products does not have an adverse effect on human health as defined by applicable Federal regulations.

- The substance's primary use is not as a preservative or to recreate or improve flavors, colors, textures, or nutritive value during processing except where the replacement of nutrients is required by law.

- The substance is generally recognized as "Generally Recognized as Safe Food Additives" (GRAS) by the Food and Drug Administration (FDA) when used in accordance with FDA's "Good Manufacturing Practices" (GMP) and contains no residues of heavy metals or other contaminants in excess of tolerances set by FDA.

- The substance is essential for the handling of organically produced agricultural products.

"Mechanical and biological methods including but not limited to the following (Table 1) may be used to process organically produced agricultural products for the purpose of retarding spoilage or otherwise preparing the agricultural product for market" National Organic Program Rules. (Section 205.270)

Table 1. Mechanical and biological methods used for processing.

\begin{tabular}{||l|l||}
\hline \hline baking & grinding \\
\hline dehydrating & distilling \\
\hline chilling & heating \\
\hline churning & mixing \\
\hline drying & extracting \\
\hline cooking & fermenting \\
\hline preserving & curing \\
\hline separating & cutting \\
\hline freezing & $\begin{array}{l}\text { or otherwise packaging, } \\
\text { canning, jarring or enclosing } \\
\text { food in a container }\end{array}$ \\
\hline \hline
\end{tabular}

\section{Packinghouses and Processors}

See Table 2.

\section{Categories of Organic Products}

\section{Organic or $100 \%$ organic:}

- Containes $100 \%$ organic ingredients

\section{Made with organic:}

- At least $70 \%$ organic ingredients by weight or fluid volume, excluding water and salt. 
- Does not list more than three organically produced ingredients or more than three of the following food groups: beans, fish fruits, grains, herbs, meats, nuts, oil, poultry, seeds, spices, sweeteners, vegetables, or processed milk products.

- No ingredient my be produced using prohibited practices specified in section 205.301.

\section{Organic ingredient and percentage listed:}

\section{Less than $70 \%$ organic}

- The nonorganic ingredients may be produced without regard to the requirements of section 205.303.

\section{Calculating the Percentage of Organically Produced Ingredients}

The percentage of all organically produced ingredients in an agricultural product sold, labeled, or represented as 100 percent organic, organic, or that include organic ingredients must be calculated by:

- Dividing the total net weight (excluding water and salt) of combined organic ingredients at formulation by the total weight (excluding water and salt) of the finished product.

- Dividing the fluid volume of all organic ingredients (excluding water and salt) by the fluid volume if the finished product (excluding water and salt) if the product and ingredients are liquid. If the liquid product is identified on the principal display panel or information panel as being reconstituted from concentrates, the calculation should be made on the basis of single-strength concentrations of the ingredients and finished product.

- For products containing organically produced ingredients in both solid and liquid form, dividing the combined weight of the solid ingredients and the weight of the liquid ingredients (excluding water and salt) by the total weight (excluding water and salt) of the finished product. (Section 205.302) 
Table 2. Organic handling requirements including packinghouses and processors.

\begin{tabular}{|c|c|c|}
\hline \multicolumn{3}{|c|}{$\begin{array}{l}\text { Nonagricultural (nonorganic) substances allowed as ingredients in or on processed products labeled as organic or made } \\
\text { with organic specified ingredients or food group(s) only in accordance with any restrictions specified in this section. } \\
\text { (Sections } 205.605 ; 205.606 \text { ) }\end{array}$} \\
\hline Nonsynthetics Allowed & Synthetics Allowed & $\begin{array}{l}\text { Nonorganically produced agricultural } \\
\text { products allowed as ingredients in or } \\
\text { on processed products labeled as } \\
\text { Organic or Made with Organic } \\
\text { (specified ingredients or food } \\
\text { groups). These products may be } \\
\text { used when not otherwise } \\
\text { commercially available in organic } \\
\text { form. }\end{array}$ \\
\hline $\begin{array}{l}\text { Acids } \\
\text { - alginic } \\
\text { - citric (produced by microbial } \\
\text { fermentation of } \\
\text { carbohydrate substances) } \\
\text { - lactic }\end{array}$ & Alginates & Cornstarch (native) \\
\hline Bentonite & $\begin{array}{l}\text { Ammonium bicarbonate - for use only as } \\
\text { a leavening agent }\end{array}$ & $\begin{array}{l}\text { Gums - water extracted only (arabic, } \\
\text { guar, locust bean, carob bean) }\end{array}$ \\
\hline Calcium carbonate & $\begin{array}{l}\text { Ammonium carbonate - for use only as a } \\
\text { leavening agent }\end{array}$ & $\begin{array}{l}\text { Kelp - for use only as a thickener and } \\
\text { dietary supplement }\end{array}$ \\
\hline Calcium chloride & Ascorbic acid & Lecithin - unbleached \\
\hline $\begin{array}{l}\text { Colors from nonsynthetic sources } \\
\text { only }\end{array}$ & Calcium citrate & Pectin (high methoxy) \\
\hline Dairy cultures & Calcium hydroxide & \\
\hline $\begin{array}{l}\text { Diatomaceous earth as a food } \\
\text { filtering aid only }\end{array}$ & $\begin{array}{l}\text { Calcium phosphates (monobasic, } \\
\text { dibasic, and tribasic) }\end{array}$ & \\
\hline $\begin{array}{l}\text { Enzymes derived fbrom edible, } \\
\text { nontoxic plants, nonpathogenic } \\
\text { fungi, or nonpathogenic bacteria. }\end{array}$ & Carbon dioxide & \\
\hline $\begin{array}{l}\text { Flavors from nonsynthetic sources } \\
\text { only and must not be produced } \\
\text { using synthetic solvents and carrier } \\
\text { systems or any artificial } \\
\text { preservative }\end{array}$ & $\begin{array}{l}\text { Chlorine materials - disinfecting and } \\
\text { sanitizing food contact surfaces. Except, } \\
\text { that, residual chlorine levelslin the water } \\
\text { shall not exceed the maximum residual } \\
\text { disinfectant limit under the Safe Drinking } \\
\text { Water Act } \\
\text { - Calcium hypochlorite } \\
\text { - Chlorine dioxide } \\
\text { - Sodium hypochlorite }\end{array}$ & \\
\hline Kaolin & $\begin{array}{l}\text { Ethylene - allowed for postharvest } \\
\text { ripening of tropical fruit }\end{array}$ & \\
\hline $\begin{array}{l}\text { Magnesium sulfate from } \\
\text { nonsynthetic sources only }\end{array}$ & $\begin{array}{l}\text { Ferrous sulfate - for iron enrichment or } \\
\text { fortification of foods when required by } \\
\text { regulation or recommended } \\
\text { (independent organization) }\end{array}$ & \\
\hline Nitrogen - oil-free grades & $\begin{array}{l}\text { glycerides (mono and di) for use only in } \\
\text { drum drying of food }\end{array}$ & \\
\hline Oxygen - oil-free grades & $\begin{array}{l}\text { Glycerin - produced by hydrolysis of fats } \\
\text { and oils }\end{array}$ & \\
\hline $\begin{array}{l}\text { Perlite - used only as a filter aid in } \\
\text { food processing }\end{array}$ & Hydrogen peroxide & \\
\hline
\end{tabular}


Table 2. Organic handling requirements including packinghouses and processors.

\begin{tabular}{|c|c|c|}
\hline \multicolumn{3}{|c|}{$\begin{array}{l}\text { Nonagricultural (nonorganic) substances allowed as ingredients in or on processed products labeled as organic or made } \\
\text { with organic specified ingredients or food group(s) only in accordance with any restrictions specified in this section. } \\
\text { (Sections } 205.605 ; 205.606 \text { ) }\end{array}$} \\
\hline Nonsynthetics Allowed & Synthetics Allowed & $\begin{array}{l}\text { Nonorganically produced agricultural } \\
\text { products allowed as ingredients in or } \\
\text { on processed products labeled as } \\
\text { Organic or Made with Organic } \\
\text { (specified ingredients or food } \\
\text { groups). These products may be } \\
\text { used when not otherwise } \\
\text { commercially available in organic } \\
\text { form. }\end{array}$ \\
\hline Potassium chloride & Lecithin - bleached & \\
\hline Potassium iodide & $\begin{array}{l}\text { Magnesium carbonate - for use only in } \\
\text { agricultural products labeled made with } \\
\text { organic (specified ingredients or food } \\
\operatorname{group}(s)\end{array}$ & \\
\hline Sodium bicarbonate & $\begin{array}{l}\text { Magnesium chloride - derived from sea } \\
\text { water }\end{array}$ & \\
\hline Sodium carbonate & $\begin{array}{l}\text { Magnesium stearate - for use only in } \\
\text { agricultural products labeled made with } \\
\text { organic (specified ingredients or food } \\
\text { group(s) prohibited in agricultural } \\
\text { products labeled organic }\end{array}$ & \\
\hline $\begin{array}{l}\text { Waxes - nonsynthetic } \\
\text { - Carnauba wax } \\
\text { - Wood resin }\end{array}$ & $\begin{array}{l}\text {-Nutrient vitamins and minerals, in } \\
\text { accordance with } 21 \text { CFR } 104.20 \text {, } \\
\text { Nutritional Quality Guidelines for Food } \\
\text { http://vm.cfsan.fda.gov/ Ird/CF104- } \\
20 . \text { HTML }\end{array}$ & \\
\hline \multirow[t]{7}{*}{$\begin{array}{l}\text { Yeast -nonsynthetic, growth on } \\
\text { petrochemical substrate and sulfite } \\
\text { waste liquor is prohibited. } \\
\text { - Autolysate } \\
\text { - Bakers } \\
\text { - Brewers } \\
\text { - Nutritional } \\
\text { - Smoked - nonsynthetic smoke } \\
\text { flavoring process must be } \\
\text { documented }\end{array}$} & Ozone & \\
\hline & Pectin (low-methoxy) & \\
\hline & $\begin{array}{l}\text { Phosphoric acid - cleaning of } \\
\text { food-contact surfaces and equipment } \\
\text { only }\end{array}$ & \\
\hline & Potassium acid tartrate & \\
\hline & $\begin{array}{l}\text { Potassium tartrate made from tartaric } \\
\text { acid }\end{array}$ & \\
\hline & Potassium carbonate & \\
\hline & Potassium citrate & \\
\hline
\end{tabular}


Table 2. Organic handling requirements including packinghouses and processors.

\begin{tabular}{|c|c|c|}
\hline \multicolumn{3}{|c|}{$\begin{array}{l}\text { Nonagricultural (nonorganic) substances allowed as ingredients in or on processed products labeled as organic or made } \\
\text { with organic specified ingredients or food group(s) only in accordance with any restrictions specified in this section. } \\
\text { (Sections } 205.605 ; 205.606 \text { ) }\end{array}$} \\
\hline \multirow[t]{11}{*}{ Nonsynthetics Allowed } & Synthetics Allowed & $\begin{array}{l}\text { Nonorganically produced agricultural } \\
\text { products allowed as ingredients in or } \\
\text { on processed products labeled as } \\
\text { Organic or Made with Organic } \\
\text { (specified ingredients or food } \\
\text { groups). These products may be } \\
\text { used when not otherwise } \\
\text { commercially available in organic } \\
\text { form. }\end{array}$ \\
\hline & $\begin{array}{l}\text { Potassium hydroxide - prohibited for use } \\
\text { in lye peeling of fruits and vegetables }\end{array}$ & \\
\hline & $\begin{array}{l}\text { Potassium iodide - for use only in } \\
\text { agricultural products labeled made with } \\
\text { organic (specified ingredients or food } \\
\text { group(s) prohibited in agricultural } \\
\text { products labeled organic }\end{array}$ & \\
\hline & $\begin{array}{l}\text { Potassium phosphate - for use only in } \\
\text { agricultural products labeled made with } \\
\text { organic (specified ingredients or food } \\
\text { group(s) prohibited in agricultural } \\
\text { products labeled organic }\end{array}$ & \\
\hline & Silicon dioxide & \\
\hline & Sodium citrate & \\
\hline & $\begin{array}{l}\text { Sodium hydroxide - prohibited for use in } \\
\text { lye peeling of fruits and vegetables }\end{array}$ & \\
\hline & $\begin{array}{l}\text { Sodium phosphates - for use only in } \\
\text { dairy foods }\end{array}$ & \\
\hline & $\begin{array}{l}\text { Sulfur dioxide - for use only in wine } \\
\text { labeled made with organic grapes, } \\
\text { Provided that total sulfite concentrations } \\
\text { does not exceed } 100 \text { ppm }\end{array}$ & \\
\hline & $\begin{array}{l}\text { Tocopherols - derived from vegetable oil } \\
\text { when rosemary extracts are not a } \\
\text { suitable alternative }\end{array}$ & \\
\hline & Xanthan gum & \\
\hline
\end{tabular}

